\title{
JOHN M. COOK (I9IO-I994): A BIBLIOGRAPHY
}

JoHN COOK, whose distinguished career included nine years (1946-54) as Director of the British School at Athens, was a scholar of great industry, insight, and originality, and a teacher and colleague of exceptional warmth and generosity. This bibliography is intended partly as a tribute to the man and his work, partly as an aid to others whose interests are contingent on his own.

The publications are listed under headings which represent his main areas of scholarly activity and, within these, are divided by format (books, articles, reviews), each category being arranged chronologically (although some publications, such as his contributions to Archaeological Reports, are grouped together for convenience). The changing focuses of his activity can be identified by scrutinizing the chronology of the works listed in each major category.

The bibliography was initially compiled by RLNB and revised, categorized, and prepared for publication by KAS, who also traced some additional entries. We have tried to ensure that it is complete. We are very grateful for the interest and assistance of Mrs Nancy Cook. The system of abbreviations adopted is that of this journal.

University of Edinburgh

R. L. N. BARBER

American School of Classical Studies at Athens

KeNNETH A. SHEEDY

\section{On The Life of J. M. CoOK}

Excerpts from the diary of J. M. Cook (privately circulated by Mrs N. Cook):

1. Greece in the 1930 .

2. In the Mountains of Greece (1943-4).

3. A Fifteen-Day Visit to Athos (September 1945).

H. Waterhouse, The British School at Athens. The First Hundred Years (London, 1986), passim, index p. 66.

\section{The Publications of J. M. Cook}

I. ASIA MINOR: ARCHAEOLOGY, TOPOGRAPHY, AND HISTORY

Books

1. The Greeks in Ionia and the East (London, I962) (later trans. as I greci dell'Asia minore (1964)).

2. The Sanctuary of Hemithea at Kastabos (London, 1966) (with W. H. Plommer).

3. The Troad: An Archaeological and Historical Study (Oxford, 1973).

4. The Persian Empire (London, I983).

Articles

5. 'Greek Archaeology in Western Asia Minor', $A R$ 1959-60, 27-57.

6. 'Greek Archaeology in Western Asia Minor', $A R$ 1964-5, 32-62 (with D. J. Blackman).

7. 'Greek Archaeology in West Asia Minor 1965-70', $A R$ 1970-1, 23-62 (with D. J. Blackman).

8. 'The Cnidia', BSA 47 (1952), I7I-212.

9. 'Excavations at Old Smyrna', Illustrated London News, 28 Feb. 1953 (with E. Akurgal).

10. 'The Topography of Klazomenai', Arch. Eph. 1953/4, (B), I49-57.

11. 'The Pali-Names', Historia, 4 (1955/6), 39-45.

12. 'The Halicarnassus Peninsula', $B S A$ 50 (1955), 85-17 ( with G. E. Bean).

3. 'The Reliefs of "Sesostris" in Ionia', Türk. Ark. Derg. 6/2 (1956), 59-65.

14. 'The Carian Coast III', BSA 52 (1957), 58-146 (with G. E. Bean). 
15. 'Old Smyrna 1948-195I', BSA 53/4 (1958/9), I-34.

16. 'Explorations at Pazarlık i959', Türk. Ark. Derg. Io/i (1960), I6-17.

r7. 'Some Sites of the Milesian Territory', $B S A 5^{6}$ (1961), 90-10г.

18. 'Cnidian Peraea and Spartan Coins', $7 H S$ 81 (1961), 56-72.

19. 'The Shrine of a Greek Demi-Goddess Revealed on the Cioast of Asia Minor: The 2400-Year-Old Temple of Hemithea, near Pazarlik', Illustrated London.News, 238 (I96I), 75-2.

20. 'Pazarlık 1960', Türk. Ark. Derg. II I (196I), I5-17.

21. 'The Problem of Classical Ionia', PCPS, n.s. 7 (196r), 9-18.

22. 'The Clarian Oracle for the Smyrnaeans', $C R$, n.s. II (1961), 7-8.

23. 'Old Smyrna: Ionic Black Figure and Other Sixth-Century Figured Ware', BSA 6o (1965), 114-42.

24. 'Old Smyrna: Fourth-Century Black Glaze', BSA 6o (1965), I43-53.

25. 'On Some Inscriptions of the Milesian Islands', $B S A 62$ (1967), $1-3$.

26. 'Coins from an Aeolic Site', BSA 63 (1968), $33-40$.

27. 'Greek Settlement in the Eastern Aegean and Asia Minor', $C A H$ ii $^{2}$ (1975), 773-804.

28. 'Bronze Age Sites in the Troad', in R. A. Crossland and A. Birchall (eds), Bronze Age Migrations in the Aegean (Sheffield, 1973), 37-40.

29. 'The Topography of the Plain of Troy', in L. Foxhall and J. K. Davies (eds), The Trojan War: Its Historicity and Context (Liverpool, 1981), $163-76$.

30. 'East Greece', $C A H$ iii' (1982), $745-78$.

31. 'The Eastern Greeks', $C A H$ iii $^{3}\left(\mathrm{I}^{82}\right)$, 196-221.

32. 'On the Date of Alyattes' Sack of Smyrna', BSA 80 (1985), $25^{-8}$.

33. 'The Rise of the Achaemenids and Establishment of Their Empire', Cambridge History of Iran, ii (Cambridge, I985), $200-9$ I.

34. 'Troy and the Sea', Anadolu, 2I (1978-80 [1987]), 75-8.

35. 'Cities in and around the Troad', BSA 83 (1988), $7^{-19}$.

36. Study on Old Smyrna (with R. V. Nicholls), forthcoming.

Reviewes

37. A. M. Mansel, Die Ruinen von Side, $7 H S 8_{4}$ (1964), 215.

38. G. E. Bean, Aegean Turkey: An Archaeological Guide, Ant. f. 46 (1966), 344-5.

39. G. L. Huxley, The Early Ionians, $C R$, n.s. 17 (1967), $113^{-14}$.

40. G. Kleiner, Alt-Milet, Gnomon, 39 (1967), 212-I4.

41. J. Boardman, Excavations in Chios: Greek Emporio, $C R$, n.s. I8 (I968), $97-9$.

42. G. Kleiner, P. Hommel, and W. Müller-Wiener, Panionion und Melie, Gnomon, 41 (1969), 716-18.

43. Id., Archaeology, 1970, I70.

44. W. Bendt, Milet II. 4, Ergebnisse der Ausgrabungen und Untersuchungen seit dem Jahre I8gg: Topographische Karte von Milet; G. Kleiner, Die Ruinen von Milet, Gnomon, 42 (1970), 2 I I-12.

45. W. Radt, Siedlungen und Bauten auf der Halbinsel von Halikarnassos, A7A 75 (1971), 445-6.

46. R. Salditt-Trappmann, Tempel der ägyptischen Götter in Griechenland und an der Westküste Kleinasiens, CR, n.s. 23 (1973), Iog.

47. W. Voigtländer, Der jüngste Apollontempel von Didyma: Geschichte seines Baudekors, $7 H S$ 96 (1976), 243-4.

48. P. Roos, The Rock Cut Tombs of Caunus, ii: The Finds, 7 HS 95 (1975), 273-4.

49. K. Tuchelt, Vorarbeiten zu einer Topographie von Didyma, JHS $_{95}$ (1975), 274.

50. P. Demargne $e t$ al., Tombes-maisons, tombes rupestres et sarcophages $=$ Fouilles de Xanthos V, JHS 96 (1976), 243.

51. J. Bouzek (ed.), Anatolian Collection of Charles University = Kyme I, JHS 97 (1977), 218.

52. H.-G. Buchholz, Methymna, $7 H S 98$ (1978), 228.

53. G. E. Bean, Lycian Turkey: An Archaeological Guide, JHS roo (1980), 272.

54. W. A. P. Childs, The City Reliefs of Lycia, $\mathcal{J} H S$ ioo (1980), 279.

55. A. Salač and J. Nepomucký, The Results of the Czechoslovak Expedition =Kyme II, JHS 102 (1982), 283.

56. J. Schäfer (ed.), Phaselis: Beiträge zur Topographie und Geschichte der Stadt und ihrer Häfen, $7 H_{S} 103$ (1983), 218.

57. Labraunda. Sivedish Excavations and Researches I. 3: Temple of Zeus (P. Hellström and T. Thieme); II. 3: Archaic Pottery

(J. J. Jully), $7 H S_{\text {IO4 }}(\mathrm{I} 984), 250-\mathrm{I}$

II. GREECE：ARCHAEOLOGICAL AND TOPOGRAPHICAL STUDIES

Books

r. Works of Art in Greece, the Greek Islands and the Dodecanese: Losses and Survivals in the War (London, I946). 
Articles

'Archaeology in Greece':

2. $1945^{-6}, \mathcal{7} H S 66$ (1946), 108-21.

3. 1947-8, JHS 67 (1947), 34-45.

4. I $948-9,7 H S 70$ (1950), I-I5.

5. $1949^{-} 5^{\circ}, 7 H S_{71}(1951), 233^{-53}$.

6. I951, $7 H S 72$ (1952), 92-1 2.

7. $1952,7 H S 73$ (1953), $108-30$.

8. I953, $7 H S 74$ (1954), 142-69 (with J. Boardman).

9. 'Finds in Various Localities', $F A$ I (1946), $96-7$.

ro. 'Laconia', BSA 45 (I950), 26I-82 (with R. V. Nicholls).

r1. 'Mycenae 1939-1952. Pt. 4. The Epano Phournos Tholos Tomb', BSA $4^{8}$ (1953), 69-83 (with M. S. F. Hood and A. J. B. Wace).

12. 'Mycenae, the Agamemneion', $B S A 48$ (1953), 30-68.

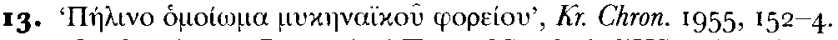

14. 'On Stephanus Byzantius' Text of Strabo', $7 H S$ 79 (I959), I9-26.

15. 'Pliny on Icarian Shores', CQ n.s. 9 (1959), I16-25.

16. 'Bath-Tubs in Ancient Greece', G\&R, and ser., 6 (1959), $3^{\mathrm{I}-4 \mathrm{I}}$.

17. 'Greece at the End of the Dark Ages', The Listener, I Jan. 1959, I7-19.

18. 'Two Notes on the Homeric Catalogue', $S M E A$ ig67, 2, I03-9.

19. Obituary of Sylvia Benton, $B S A$ 8 I (1986), pp. vii-x.

\section{Reviews}

20. W. Vollgraff, Le sanctuaire d'Apollon Pythéen à Argos, $7 H S 79$ (1959), 219-20.

21. N. Lewis, Samothrace I: The Ancient Literary Sources, CR, n.s. Io (I96o), 267.

22. P. M. Fraser, Samothrace II. I: The Inscriptions on Stone; K. Lehmann, Samothrace II. 2: The Inscriptions on Ceramics, CR, n.s. I2 (1962), 100-1.

23. K. Lehmann, Samothrace IV. I: The Hall of Votive Gifts, CR, n.s. I4 (1964), 117-18.

24. K. Lehmann and D. Spittle, Samothrace IV. 2: The Altar Court, CR, n.s. 15 (1965), I30-I.

25. P. W. Lehmann, Samothrace III: The Hieron, CR, n.s. 21 (1971), 272-4.

26. J. L. Benson, Ancient Leros, CR, n.s. I4 (1964), 355-6.

27. J. R. McCredie, Fortified Military Camps in Attica, CR, n.s. i7 (1967), 363-5.

28. N. G. L. Hammond, Epirus, Ant. 7. $4^{8}$ (1968), го9-го.

29. W. R. Pritchett, Studies in Ancient Greek Topography, Part II (Battlefields), CR, n.s. 22 (1972), I30-I.

3o. F. E. Winter, Greek Fortifications, $C R$, n.s. 23 (1973), 284-5.

31. H. A. Thompson and R. E. Wycherley, The Agora of Athens $=7$ the Athenian Agora XIV, CR, n.s. 25 (I975), 289-9I.

32. B. Schmaltz, Das Kabirenheiligtum bei Theben V, CR, n.s. 26 (1976), 293.

33. J. Boardman and J. Hayes, Excavations at Tocra $1963-1965, C R$, n.s. 26 (1976), 294.

34. O. Broneer, Isthmia II: Topography and Architecture, CR, n.s. 26 (1976), 295.

35. R. Hägg, Die Gräber der Argolis in submykenischer, protogeometrischer und geometrischer Žeit, CR, n.s. 27 (1977), 304-5.

III. ATTIC GEOMETRIC AND PROTOATTIC POTTERY (AND OTHER GREEK POTTERY STUDIES)

Articles

1. 'Protoattic Pottery', BSA 35 (1934/5), 165-219.

2. 'A Geometric Graveside Scene', $B C H$ 7о (1946), 97-гог.

3. 'Athenian Workshops around 7oo', $B S A 4^{2}$ (I947), 139-55.

4. 'A Geometric Amphora and Gold Band', BSA 46 (I95I), 45-9.

5. 'Vasi protoattici', EAA 6 (1965), 495-504.

6. 'A Painter and his Age', in Mélanges André Varagnac (Paris, I97ı), I67-76.

Reviews

7. CVA Deutschland 2, 7HS 59 (1939), I5I.

8. K. Kübler, Altattische Malerei, Gnomon, 23 (195I), 212-I4.

9. W. Kraiker, Aigina. Die Vasen des 10. bis 7. Jahrhunderts v. Chr., A7A 56 (1952), 220-1.

10. CVA Deutschland $9,7 H S_{75}$ (1955), 181-2. 
I1. K. Kübler, Kerameikos V. I: Die Nekropole des ro. bis 8 . Jahrhunderts, $7 H S$ 76 (1956), 124-5.

12. CVA Great Britain $12,7 H S$ 76 (1956), I33.

13. CVA Denmark 1, JHS 77 (1957), 35 o.

14. K. Kübler, Kerameikos VI: Die Nekropole des späten 8. bis frühen 6. Zh., Gnomon, 32 (1960), 715-18.

15. H. S. Robinson, Pottery of the Roman Period: Chronology = The Athenian Agora V, CR, n.s. 10 (1960), 267-8.

16. CVA Deutschland ${ }_{15}$; R. Hampe, Ein frühattischer Grabfund, 7HS 81 (1961), 220.

17. E. T. H. Brann, Late Geometric and Protoattic Pottery, Mid 8th to Late 7 th Century BC $=$ The Athenian Agora VIII, Gnomon, 34 (1962), 820-3.

18. J. N. Coldstream, Greek Geometric Pottery, CR, n.s. 20 (1970), $226-7$.

19. CVA Deutschland 28, Gnomon, 42 (1970), 314-15.

20. R. S. Folsom, Handbook of Greek Pottery, J 7 HS 88 (1968), 234

21. A. D. Trendall, The Red-Figured Vases of Lucania, Campania and Sicily, CR, n.s. I8 (1968), 359-6o.

22. W. Schiering, Griechische Tongefäße: Gestalt, Bestimmung und Formenwandel, $7 H S$ S9 (1969), 191.

23. B. Schweitzer, Die geometrische Kunst Griechenlands, $7 H S$ 90 (1970), 259-6o.

24. J. L. Benson, Horse, Bird and Man, $7 H S 91$ (1971), 206-7.

25. F. Brein, Der Hirsch in der griechischen Frühzeit, CR, n.s. 22 (1972), 119-20.

26. B. A. Sparkes and L. Talcott, Black and Plain Pottery = The Athenian Agora XII, CR, n.s. 23 (1973), 71-2.

27. W-D. Heilmeyer, Frühe olympische Tonfiguren = Olympische Forschungen XII, CR, n.s. 25 (1975), 158.

28. W. Gauer, Die Tongefäße aus den Brunnen unterm Stadion-Nordwall und im Südost-Gebiet=Olympische Forschungen VIII, $C R$, n.s. 27 (1977), 305 .

\section{GREEK ART AND OTHER TOPICS}

Reviezes

1. L. E. Lord, A History of the American School of Classical Studies at Athens, JHS 69 (1949), 99 .

2. Commemorative Studies in Honor of Theodore Leslie Shear (Hesp. Supp. 8), JHS 70 (1950), $89-90$.

3. Anatolian Studies I, $7 H{ }_{73}$ (1953), 146.

4. R. Hampe, Die Gleichnisse Homers und die Bildkunst seiner Zeit (Die Gestalt, 22), $7 H S$ 74 (1954), 243.

5. D. Ohly, Griechische Goldbleche des 8. Jh. v. Chr., Gnomon, 26 (1954), 107-10.

6. A. Philippson, Die griechischen Landschaften: eine Landeskunde, i, $\mathcal{J} H S_{75}$ (1955), I56-7.

7. Id., ii, $7 \mathrm{HS}_{7} 8$ (1958), 153-5.

8. G. E. Mylonas and D. Raymond (eds), Studies Presented to David Moore Robinson, $7 H S 75$ (1955), 157.

9. G. M. A. Richter, Catalogue of Greek Sculptures (Metropolitan Museum), Antiquity 29 (1955), 245-6.

10. R. Lullies (ed.), Neue Beiträge zur klassischen Altertumswissenschaft (Festschrift B. Schweitzer), $7 H S 76$ (1956), 123.

11. Ch. Picard, Manuel d'archéologie grecque Vol. IV, JHS 76 (1956), 129-30.

12. U. Jantzen, Griechische Greifenkessel, $7 H S$ 77 (1957), 36 г.

3. G. M. A. Richter, Ancient Italy, Ant. J. 37 (1957), 77-8.

14. D. von Bothmer, Amazons in Greek Art, Ant. J. $3^{8}$ (1958), 98-9.

15. K. Schauenberg (ed.), Charites: Studien zur Altertumswissenschaft, $7 H S 79$ (1959), 198-9.

6. E. Meyer, Neue peloponnesische Wanderungen, CR, n.s. 29 (I959), 84-5.

17. T. B. L. Webster, From Mycenae to Homer, Ant. J. 39 (1959), IoI-2.

18. E. Simon, Die Geburt der Aphrodite, Ant. J. 39 (1959), 300.

19. G. M. A. Richter, A Handbook of Greek Art, Ant. J. 39 (1959), 300.

2o. Id., $C R$, n.s. Io (ig6o), I77.

21. Ch. Dugas and R. Flacelière, Thésée: images et récits, CR, n.s. Io (I960), 8I.

22. H.-V. Herrmann, Omphalos, CR, n.s. Io (I96o), 266-7.

23. R. A. Higgins, Catalogue of the Terracottas, British Museum, i/2. 2, Ant. 7. 40 (1960), 232.

24. P. Corbett, The Sculpture of the Parthenon, $C R$, n.s. I I (196r), 94 .

25. T. Burton-Brown, Early Mediterranean Migrations, $C R$, n.s. II (I96I), I7I.

26. A. T. Hodge, The Woodwork of Greek Roofs, CR, n.s. II (I96I), 278-80.

27. D. Sicilianos, Old and New Athens, CR, n.s. I I (I961), 309-1o.

28. R. Carpenter, Greek Sculpture, $7 H S$ 82 (I962), $201-2$.

29. J. Boardman, The Cretan Collection in Oxford: The Dictaean Cave and Iron Age Crete, Ant. J. 42 (1962), 260.

3o. R. E. Wycherley, How the Greeks Built Cities, $C R$, n.s. 14 (1964), 117.

31. B. Ashmole, Some Nameless Sculpture of the Fifth Century $B C, C R$, n.s. I4 (1964), 357-8.

32. J. Boardman, Island Gems, CR, n.s. 14 (1964), 358-9. 
33. J. Boardman, The Greeks Overseas, $C R$, n.s. I 5 (1965), 95-7.

34. G. Pentreath, Hellenic Traveller: $A$ Guide to the Ancient Sites of Greece and the Aegean, CR, n.s. ${ }_{5}$ (1965), $105^{-6}$.

35. M. Wegner, Sizilien: Charakterstudie einer Wettinsel, $C R$, n.s. I5 (Ig65), I29-30.

36. T. B. L. Webster, Hellenistic Poetry and Art, CR, n.s. I5 (I965), $3^{21-2 .}$

37. M. Lang and M. Crosby, Weights, Measures and Tokens = The Athenian Agora X, CR, n.s. I5 (1965), 348-9.

38. L. Budde and R. V. Nicholls, A Catalogue of the Greek and Roman Sculpture in the Fitzwilliam Museum, CR, n.s. 15 (1965), 349-5o.

39. J. Simons, Pausanias, Rejseforer gennem Grakenland, $C R$, n.s. I6 (Ig66), i 6.

4o. B. H. Hill, The Springs Peirene, Sacred Spring, and Glauke = Corinth I. 6, CR, n.s. 16 (1966), 418-19.

4r. W. Atallah, Adonis dans la littérature et l'art grecs, $C R$, n.s. 17 (1967), $77-9$.

42. H.-V. Herrmann, Die Kessel der orientalisierenden Zeit, I= Olympische Forschungen VI, CR, n.s. I7 (I967), 99-10I.

43. H. Brandenburg, Studien zur Mitra, CR, n.s. I7 (1967), 106-7.

44. D. E. Strong, Catalogue of the Carved Amber in the Department of Greek and Roman Antiquities, CR, n.s. 17 (I967), I 8-19.

45. C. C. Vermeule III, The Dal Pozzo-Albani Drawings of Classical Antiquities in the Royal Library of Windsor Castle, CR, n.s. I7 (1967), 1 19-20.

46. S. Adam, The Technique of Greek Sculpture in the Archaic and Classical Periods; T. B. L. Webster, Hellenistic Art; B. Philippaki, The Attic Stamnos, CR, n.s. I 7 (1967), 37 I-5.

47. M. J. Vermaseren, The Legend of Attis in Greek and Roman Art, CR, n.s. 17 (1967), 403.

48. Letter to the Editor, Journal of the Society of Architectural Historians, 27 (1968), 93-4, responding to review of $i .2$ by

H. A. Thompson in that journal, $26(1967), 217^{-20}$.

49. W. St. Clair, Lord Elgin and the Marbles, $C R$, n.s. I8 (I968), 249.

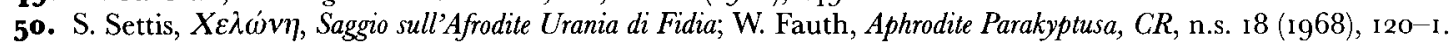

5I. M.-P. Loicq-Berger, Syracuse: histoire culturelle d'une cité grecque, $C R$, n.s. 18 (1968), 240-1.

52. K. Schefold, Classical Greece, CR, n.s. 18 (1968), 340-I.

53. R. A. Higgins, Greek Terracottas, $C R$, n.s. I8 (1968), 359

54. P. Devambez, A Dictionary of Ancient Greek Civilization, $C R$, n.s. 18 (1968), 362 .

55. J. Boardman, Archaic Greek Gems, Ant. J. 49 (I969), 416-i 7.

56. J. S. Morrison and R. T. Williams, Greek Oared Ships, CR, n.s. I9 (Ig69), 227-9.

57. E. Kjellberg and G. Säflund, Greek and Roman Art 3000 BC to AD 50o, CR, n.s. I9 (1969), 247-8.

58. G. Becatti, The Art of Ancient Greece and Rome, CR, n.s. 19 (1969), 350-1.

59. J. V. Luce, The End of Atlantis, CR, n.s. 20 (1970), 224-5.

6o. M. Grant, The Ancient Mediterranean, $C R$, n.s. 20 (1970), 251-2.

6r. G. Säflund (ed.), Opuscula C. Kerényi dedicata, CR, n.s. 20 (1970), 260-I.

62. E. Meyer, Heinrich Schliemann, CR, n.s. 20 (1970), 390-2.

63. R. Hope Simpson and J. F. Lazenby, The Catalogue of Ships in Homer's Iliad, CR 21 (1971), 173-4.

64. R. Weiss, The Renaissance Discovery of Classical Antiquity, $C R$, n.s. 21 (1971), 279.

65. U. Hausmann (ed.), Allgemeine Grundlagen der Archäologie, CR, n.s. 2I (1971), 429-31.

66. J. Pinsent, Greek Mythology; S. Perowne, Roman Mythology, $C R$, n.s. 2 I (I971), 466-67.

67. O. Schönberger, Philostratos, Die Bilder (Eikones), CR, n.s. 22 (1972), 105-6.

68. W. K. Pritchett, Studies in Ancient Greek Topography, Pt. 2, CR, n.s. 22 (1972), I30-1.

69. F. M. Snowden, Blacks in Antiquity, CR, n.s. 22 (1972), 253-5.

70. A. G. Ward, The Quest for Theseus, CR, n.s. 22 (1972), 288-9.

7r. C. W. Clairmont, Gravestone and Epigram, CR, n.s. 22 (1972), 292.

72. E. Gullberg and P. Åström, The Thread of Ariadne, CR, n.s. 22 (I972), 293-4.

73. S. Piblis, Panathenaea, $C R$, n.s. 22 (1972), 431.

74. E. A. S. Butterworth, The Tree at the Navel of the Earth, CR, n.s. 22 (1972), 430-I.

75. J. S. Boersma, Athenian Building Policy from $561 / 0$ to $405 / 4, C R$, n.s. 23 (1973), 106.

76. F. E. Winter, Greek Fortifications, $C R$, n.s. 23 (1973) $284-5$.

77. F. Hiller, Formgeschichtliche Untersuchungen zur griechischen Statue, and W. Leppmann, Winckelmann, CR, n.s. 23 (1973), 290-I.

78. B. Ashmole, Architect and Sculptor in Classical Greece, $7 H S 93$ (1973), 264.

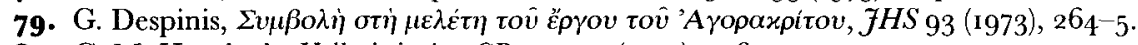

8o. C, M. Havelock, Hellenistic Art, CR, n.s. 24 (1974), ro6-7.

81. O. Broneer, Isthmia I: Temple of Poseidon, CR, n.s. 24 (1974), I22-3.

82. F. W. Goethert, Katalog der Antikensammlung des Prinzen Carl von Preußen, CR, n.s. 24 (1974), 307. 
83. F. Hölscher, Die Bedeutung archaischer Tierkampfbilder, 7 HS 94 (1974), $247-8$.

84. J. B. Ward-Perkins, Cities of Ancient Greece and Italy, Times Literary Supplement, 9 Aug. 1974.

85. A. Burford, Craftsmen in Greek and Roman Society, CR, n.s. 25 (1975), 74-5.

86. J. Charbonneaux, R. Martin, F. Villard, Classical Greek Art, 480-330 BC, CR, n.s. 25 (I975), $294-5$.

87. J. Boardman, Greek Art, CR, n.s. 25 (1975), 327.

88. H. Bloesch, Zur griechischen Kunst, CR, n.s. 25 (I975), 332-3.

89. R. V. Schoder, Ancient Greece from the Air, Times Literary Supplement, 2 I Feb. 1975.

9o. M. C. Şahin, Die Entriicklung der griechischen Monumentalaltäre, $7 H S 95$ (1975), 282-3.

9r. B. Dicks, Rhodes, $C R$, n.s. 26 (1976), 288.

92. C. Berard, Anodoi, CR, n.s. 26 (1976), $29^{2}$.

93. B. Bergquist, Herakles on Thasos, CR, n.s. 26 (1976), 292-3.

94. A. Birchall and P. E. Corbett, Greek Gods and Heroes, CR, n.s. 26 (1976), 293.

95. F. Hölscher, Griechische Historienbilder des 5. und 4. Jahrhunderts v. Chr., CR, n.s. 26 (1976), $296-7$.

96. O. W. Muscarella, Ancient Art in the Norbert Schimmel Collection, CR, n.s. 27 (1977), 83-4.

97. K. Schefold, Wort und Bild, CR, n.s. 27 (1977), 328-9.

98. R. V. Stillwell (ed.), The Princeton Encyclopedia of Classical Sites, CR, n.s. 28 (1978), 323-4.

99. P. Müller, Löwen und Mischwesen in der archaischen griechischen Kunst: eine Untersuchung über ihre Bedeutung, $7 H S$ io1 $(198 \mathrm{I}), 220$.

\section{OBITUARIES}

I. N. G. L. Hammond, The Independent, 7 Jan. I994.

2. J. Boardman, The Times, in Jan. I994.

3. R. L. N. Barber and N. K. Rutter, The Scotsman, I4 Jan. I994

4. The King's College Obituarist, The King's College, Cambridge Annual Report, November 1994.

5. M. S. F. Hood, BSAAR I993-4, 39-40.

6. J. Boardman, PBA Lectures and Memoirs, 87 (1994), 265-73.

R.L.N.B.

K.A.S. 